\begin{tabular}{|c|c|c|c|c|c|c|}
\hline \multirow{4}{*}{ Impact Factor: } & ISRA (India) & $=3.117$ & SIS (USA) & $=0.912$ & ICV (Poland) & $=6.630$ \\
\hline & ISI (Dubai, UAE & $=0.829$ & РИНЦ (Russia & $=0.156$ & PIF (India) & $=1.940$ \\
\hline & GIF (Australia) & $=0.564$ & ESJI (KZ) & $=8.716$ & IBI (India) & $=4.260$ \\
\hline & JIF & $=1.500$ & SJIF (Morocco & $=5.667$ & OAJI (USA) & $=0.350$ \\
\hline
\end{tabular}

\section{SOI: $\underline{1.1 / \mathrm{TAS}}$ DOI: $\underline{10.15863 / \mathrm{TAS}}$ \\ International Scientific Journal Theoretical \& Applied Science}

\author{
p-ISSN: 2308-4944 (print) $\quad$ e-ISSN: 2409-0085 (online) \\ Year: 2019 Issue: $05 \quad$ Volume: 73
}

Published: $30.05 .2019 \quad \underline{\text { http://T-Science.org }}$
QR - Issue

QR - Article
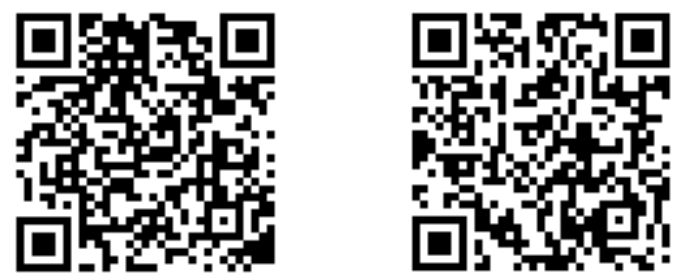

Makhamedkali Kenzhekhojayev

Candidate of Technical Sciences, Associate professor Head of the department «Technology of food products, processing industries and biotechnology»

M.Kh. DulatyTaraz State University, Kazakhstan

\title{
COMPARATIVE STUDY OF THE BIOCHEMICAL COMPOSITION OF KAZAKHSTAN RASPBERRY VARIETIES FOR DIETARY NUTRITION
}

\author{
Abstract: One of the ways to solve the current problems is the use of remontant varieties that can produce high \\ yields only on annual shoots in the fall, when the heat subsides and the plants get enough moisture. \\ There are special varieties that can produce two harvests per year - in the usual period and at the end of \\ summer - beginning of autumn. They call such varieties remontant. \\ Key words: raspberry, remontant raspberry, technological qualities, amino acids. \\ Language: English \\ Citation: Kenzhekhojayev, M. (2019). Comparative study of the biochemical composition of Kazakhstan \\ raspberry varieties for dietary nutrition. ISJ Theoretical \& Applied Science, 05 (73), 587-591. \\ Soi: http://s-o-i.org/1.1/TAS-05-73-93 Doi: crosłef https://dx.doi.org/10.15863/TAS.2019.05.73.93
}

\section{INTRODUCTION}

At present, raspberries are located mainly in the individual sectorin the south of Kazakhstan, and only some farms grow berries that are in demand by consumers under production conditions. Getting a good harvest of raspberries is extremely difficult due to the high summer temperature and low relative humidity of the air. Another reason restraining the laying of large plantations of raspberries is the considerable labor intensity of cultivation[1]. At the same time, compared to varieties with a two-year fruiting cycle, remontant raspberry varieties extend the season for consuming fresh berries until AugustOctober.

While growing remontant raspberry varieties, the entire agrotechnical process of caring for the plantation is greatly simplified, such operations as trellis installation, garter and shortening of the stems are excluded, and the costs of planting care are reduced. Cultivation of remontant raspberry varieties according to the type of annual crop removes the problem of winter stems' hardiness, and their removal from the plantation after mowing allows to get rid of the main diseases and pests without using pesticides [2].

Therefore, the task of our research is to study the quality indicators of berries of remontant varieties of raspberries grown in the south of Kazakhstan. The remontant raspberry is becoming increasingly popular among Kazakhstani amateur gardeners. This allows you to effectively use the favorable environmental factors due to the one-year cycle of the formation of technologies and the possibilities of cultivation. From remontant raspberries, you can harvest two harvests per season. Breeding can be only in conditions of intensive nutrition and abundant cultivation of the culture, otherwise the berries will be small and dry.

The resulting crop on the biennial circle will weaken the plant and delay the ripening of the second most valuable crop, so it is recommended to cut the bushes every autumn at the root. The cultivation of remontant raspberries in annual crops (with annual prewinter mowing of the aerial parts of plants) and the complete rejection of the use of pesticides provide ecological, technological and economic attractiveness to the culture [3].

In our country only one remontant variety was zoned for a long time- Babiyeleto(Indian Summer) the first industrial variety of this type. Scientists have found that raspberry berries are sources of vitamins $C$, $\mathrm{P}, \mathrm{B}$ 9. When a person ate a glass of this culture's berries and it contains enough vitamins for the whole day. And other useful substances were found in raspberries, such as compounds of phosphorus, iron, manganese, potassium, copper. They need very little for a person, his normal state of health, but if his body lacks these substances, then the body begins to ache. Sweet raspberry is obtained due to the presence of sugar in its berries (up to $12 \%$ ), the acidity in berries is provided by organic acids: malic, citric, succinic 


\begin{tabular}{|c|c|c|c|c|c|c|}
\hline \multirow{4}{*}{ Impact Factor: } & ISRA (India) & $=3.117$ & SIS (USA) & $=0.912$ & ICV (Poland) & $=6.630$ \\
\hline & ISI (Dubai, UAE & $=0.829$ & РИНЦ (Russia & $=0.156$ & PIF (India) & $=1.940$ \\
\hline & GIF (Australia) & $=0.564$ & ESJI (KZ) & $=8.716$ & IBI (India) & $=4.260$ \\
\hline & JIF & $=1.500$ & SJIF (Morocce & $=5.667$ & OAJI (USA) & $=0.350$ \\
\hline
\end{tabular}

and others (up to $2.5 \%$ ). There are some proteins in raspberry berries $(0.5-0.8 \%)$, vitamin $\mathrm{C}(10-70 \%)$, catechins (up to $80 \mathrm{mg} / \%$ ), anthocyanins (100-150 $\mathrm{mg} / \%)$. A special medicinal substance — betasitosterol, which prevents the deposition of cholesterol in the walls of blood vessels and, consequently, the occurrence of sclerosis, is found in raspberry. According to the content of this substance, raspberries can only be consumed by sea buckthorn fruits. Raspberry berries have a beneficial effect on blood formation, prevent leukemia and anemia. Vitamin B9 (salicylic acid) has bactericidal properties. Especially a lot $(0,2-0,45 \%)$ of this acid in theoverripeberries [4].

According to scientists, it is normal for the body to consume less than two kilograms of raspberry. When strawberry ends up fruiting, it begins to delight us with the raspberry crop. We collect raspberry berries, and then came the black currant. You can eat raspberries in the fall. In farms these crops are valued for their precocity (yields for the second year), yield (up to $40 \mathrm{t} / \mathrm{ha}$ ). There are litters that have berries the size of a pigeon's egg and without thorns. This useful plant is raspberry.

Biological and technological features of raspberry remontant varieties in the conditions of the south of Russia allow to get a crop from $7.5 \mathrm{t} / \mathrm{ha}$ (BabiyeLeto) to $10.0 \mathrm{t} / \mathrm{ha}$. Currently, special attention to remontant raspberry varieties is due to the fact that the cost of the crop grown in the autumn period exceeded the cost of berries grown in early summer using the traditional technology used for varieties with the usual type of fruiting. According to the results of this year, the average selling price of raspberry remontant varieties in the autumn period was 800tg / $\mathrm{kg}$.

The berries of the studied remontant varieties of raspberry growing in the south of Kazakhstan differ in size, mass, shape, color, and density of adhesion of the carpets. The varieties Heracles, Brilliyantovaya, Polyana, and BabiyeLeto are distinguished by largefruited (1 table)[5].

Table 1. Technical quality indicators of berries of raspberry repairman grades

\begin{tabular}{|l|l|l|l|}
\hline Variety & Mass of berries, $\mathrm{g}$ & The height of the berries, mm & Diameter of berries, mm \\
\hline BabiyeLeto & 2.2 & 15 & 18 \\
\hline Polyana & 2.7 & 18 & 18 \\
\hline Hercules & 3.4 & 20,3 & 19,5 \\
\hline Brilliyantovaya & 3.1 & 21.5 & 17 \\
\hline
\end{tabular}

For comparison, we took these works of T.G. Prichko: Russian varieties Kalashnik and Elegnatnaya differ from Kazakhstan varieties in size, weight and shape.
Taste and technological qualities of raspberry berries are largely determined by their chemical composition. The soluble solids of the raspberry berries of the studied varieties vary from 8.9 to $13.3 \%$ (Table 2).

Table 2. Technical quality indicators of berries of raspberry repairman grades for comparison

\begin{tabular}{|l|l|l|l|}
\hline Variety & Mass of berries, $\mathrm{g}$ & The height of the berries, mm & Diameter of berries, mm \\
\hline Kalashnik & 2.5 & 16.2 & 19 \\
\hline Elegantnaya & 2.3 & 15 & 17 \\
\hline
\end{tabular}

Polyana, Heracles, Brilliantovaya, Babiyeleto are different in maximum accumulation of soluble solids. Similar trends are observed in the level of sugars, which are almost equally represented mainly by glucose and fructose, and in small amounts by sucrose.

One of the basic qualities of berries is its taste, which is conditioned by the combination of sugar and organic acid. The berries of the raspberry have an acidic sweet taste, with this sugar-acidic index of 4.57.5 units of dependence depending on the fertile parts.
The color of raspberry berries is largely determined by the state of ripening, as well as the biologically determined characteristics of the varieties, which are associated with the presence of anthocyanins, the content of which differs by a factor of 3-4 times. According to the intensity of the color, the remontant varieties of raspberry

Brilliyantovaya, Polyana, Hercules are distinguished.

On the example of the Brilliyantovayaberries, other phenolic compounds have been identified: chlorogenic, nicotinic, caffeic, salicylic, 


\begin{tabular}{|c|c|c|c|c|c|c|}
\hline \multirow{4}{*}{ Impact Factor: } & ISRA (India) & $=3.117$ & SIS (USA) & $=0.912$ & ICV (Poland) & $=6.630$ \\
\hline & ISI (Dubai, UAE & $=0.829$ & РИНЦ (Russia & $=0.156$ & PIF (India) & $=1.940$ \\
\hline & GIF (Australia) & $=0.564$ & ESJI (KZ) & $=8.716$ & IBI (India) & $=4.260$ \\
\hline & JIF & $=1.500$ & SJIF (Morocce & $=5.667$ & OAJI (USA) & $=0.350$ \\
\hline
\end{tabular}

protocatechinic acid and resveratrol, the content of which is associated with the biological value of raspberry berries.

In berries of remontant raspberry varieties, it was found from $9.3 \mathrm{mg} / 100 \mathrm{~g}$ (Polana variety) to $1.9 \mathrm{mg}$ / $100 \mathrm{~g}$ (Brilliantovayasort) salicylic acid, which has bactericidal properties.

The content of free amino acids in raspberry berries was studied using the example of remontant varieties Indian Summer and Polana. The largest amount (61.8 mg / $100 \mathrm{~g}$ ) was found in Polana raspberry berries, which determines their therapeutic value (Table 3 ).

The presence of free amino acids, which in the studied varieties have been identified 10-12, including 5-6 essential (threonine, valine, methionine, leucine, lysine, phenylalanine), causes the therapeutic value of the berries of raspberry repair varieties (Table 4).

Table 3. Biochemical indicators of the quality of berries remontant varieties raspberries

\begin{tabular}{|c|c|c|c|c|c|c|c|}
\hline \multirow[t]{2}{*}{ Variety } & \multicolumn{7}{|c|}{ Biochemical indicators } \\
\hline & $\begin{array}{l}\text { solublesolids } \\
, \%\end{array}$ & $\begin{array}{l}\text { amountofsu } \\
\text { gars, \% }\end{array}$ & totalacidity,\% & s / c index & $\begin{array}{l}\text { vitamin } \\
\mathrm{mg} / 100 \mathrm{~g}\end{array}$ & $\begin{array}{l}\mathrm{C}, \text { vitaminP, } \\
\mathrm{mg} / 100 \mathrm{~g}\end{array}$ & $\begin{array}{l}\text { anthocyanins, } \\
\mathrm{mg} / 100 \mathrm{~g}\end{array}$ \\
\hline BabiyeLeto & 10,3 & 8,6 & 1,32 & 6,7 & 28,0 & 37 & 77,3 \\
\hline Brilliyantovaya & 9,6 & 7,6 & 1,76 & 4,6 & 22,1 & 22,3 & 93 \\
\hline Polyana & 8,1 & 7 & 1,58 & 4,3 & 21 & 10,0 & 37,5 \\
\hline Hercules & 13,5 & 10,7 & 1,39 & 7,7 & 26,4 & 15,4 & 116,2 \\
\hline Kalashnik & 10,9 & 8,3 & 1,71 & 4,3 & 16,5 & 22 & 107 \\
\hline Elegantnaya & 10,4 & 8,3 & 1,33 & 6,1 & 31 & 13,0 & 169,0 \\
\hline
\end{tabular}

The largest amount of free amino acids $(61.8 \mathrm{mg}$ / $100 \mathrm{~g}$ ) is found in Polyanka berries. Evaluation of raspberry berries in processing in the production of jam and products of rapid freezing allowed us to identify varieties that provide high-quality finished products. remontant varieties of Babiyeleto, Kalashnik, Polyanka, Hercules, Brilliyantovaya with a dense berry of sweet-sour taste and intense color, are universal. The obtained jam samples from the berries of these raspberry varieties have a pronounced aroma, bright color of the syrup, well-preserved form of the berries, which together determines a high tasting score of 7 products - 4.7-4.9 points. In canned food, a sufficiently high level of biologically active substances is maintained.

Table 4. The content of free amino acids in the berries of Kazakhstan varieties of raspberries, Babiyeleto and Polana

\begin{tabular}{|c|c|c|}
\hline \multirow[t]{2}{*}{ Name } & \multicolumn{2}{|c|}{ Grade / amino acid content, mg / $100 \mathrm{~g}$} \\
\hline & Babiyeleto & Polana \\
\hline \multicolumn{3}{|l|}{ Irreplaceable } \\
\hline Valin & 2,7 & \\
\hline Lysine & 0,19 & \\
\hline Leucine & 0,27 & \\
\hline Methionine & 1,36 & \\
\hline Threonine & 3,87 & \\
\hline Phenylalanine & 0,53 & \\
\hline \multicolumn{3}{|l|}{ Replaceable } \\
\hline \begin{tabular}{|l|} 
Alanine \\
\end{tabular} & 2,74 & 30,16 \\
\hline Arginine & 1,75 & $\underline{9,89}$ \\
\hline
\end{tabular}




\begin{tabular}{|c|c|c|c|c|c|c|}
\hline \multirow{4}{*}{ Impact Factor: } & ISRA (India) & $=3.117$ & SIS (USA) & $=0.912$ & ICV (Poland) & $=6.630$ \\
\hline & ISI (Dubai, UAI & $=0.829$ & РИНЦ (Russia) & $=0.156$ & PIF (India) & $=1.940$ \\
\hline & GIF (Australia) & $=0.564$ & ESJI (KZ) & $=8.716$ & IBI (India) & $=4.260$ \\
\hline & JIF & $=1.500$ & SJIF (Morocco) & $=5.667$ & OAJI (USA) & $=0.350$ \\
\hline
\end{tabular}

\begin{tabular}{|l|l|l|}
\hline G istidin & $\underline{0,68}$ & notupdated \\
\hline Glycine & $\underline{0,14}$ & $\underline{0,28}$ \\
\hline Serine & $\underline{0,78}$ & $\underline{5,63}$ \\
\hline Proline & $\underline{1,77}$ & $\underline{2,41}$ \\
\hline TOTAL & $\underline{18,25}$ & $\underline{61,80}$ \\
\hline
\end{tabular}

The study of raspberry berries of remontant varieties in processing in the production of jam, compotes and products of rapid freezing allowed us to identify varieties that provide high-quality finished products. Varieties of Babiyeleto, Kalashnik, Polana, Hercules, with a dense berry of sweet-sour taste and intense coloring are universal.

The obtained samples of jam and compote from the berries of these varieties have a pronounced aroma, bright color of the syrup, well-preserved form of berries, which together determines a high tasting score of 4.7-4.9 points.

Frozen products of the above raspberry varieties after defrosting retain well the shape, presentation, taste and aroma of fresh berries (Fig. 1).

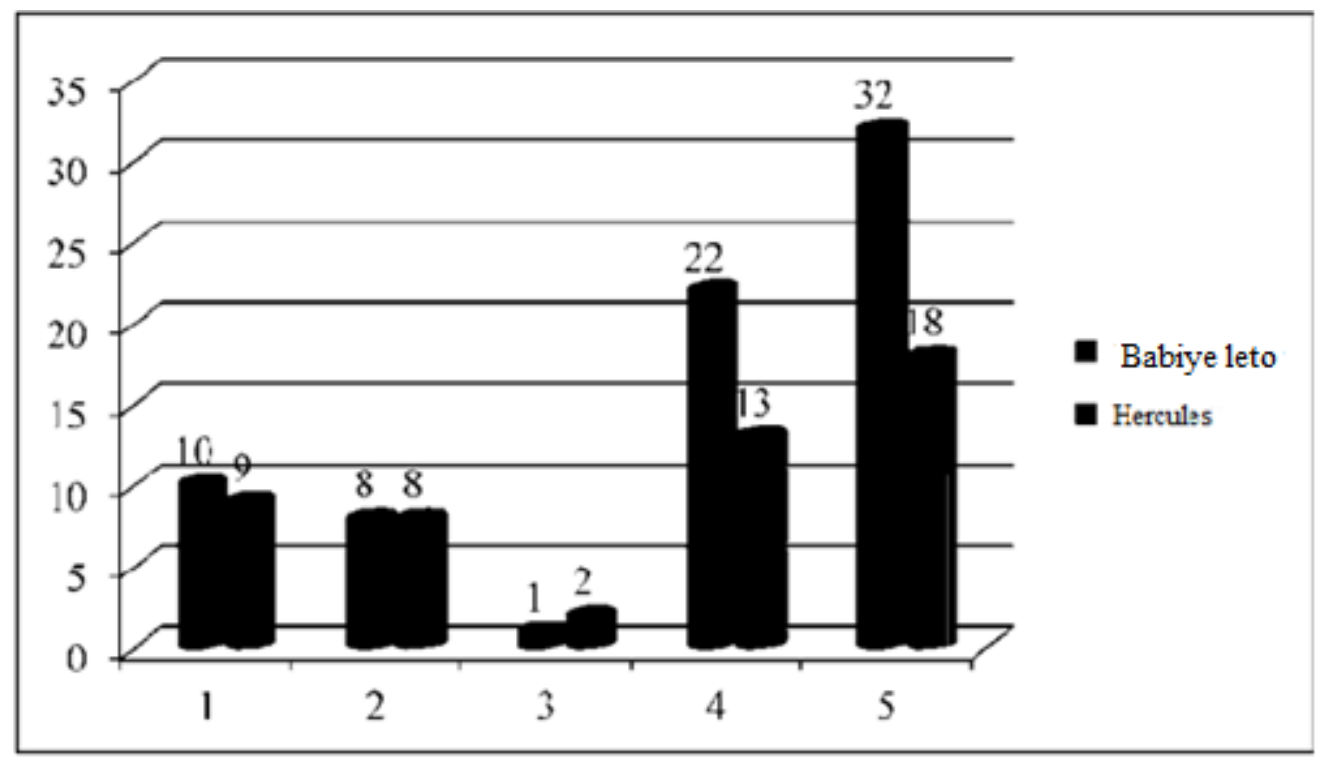

Figure 1- Biochemical parameters of Babiyeleto berries and Heracles after defrosting

The loss of juice by berries during defrosting after 6 months of storage is from $0.6 \%$ Polana variety) to $1.2 \%$ (Babiyeletosort). The preservation of vitamin $\mathrm{C}$ in this case reaches $75-79 \%$ of the original, $\mathrm{P}$-active substances - 90-98\%.
The loss of juice by berries during defrosting after 6 months of storage ranges from $0.6 \%$ (Polyankasort) to $1.2 \%$ (Babiyeleto variety). The preservation of vitamin $\mathrm{C}$ in this case reaches $75-79 \%$, P-active substances - 90-98\% (Table 5).

Table 5. Biochemical parameters of berries of raspberry remontant varieties after defrosting

\begin{tabular}{|l|l|l|l|l|l|}
\hline Biochemical quality indicators & Soluble solids, \% & $\begin{array}{l}\text { The amount of Total acidity, } \\
\text { sugars } \\
\%\end{array}$ & $\begin{array}{l}\text { vitamin C, mg } \\
100 \mathrm{~g}\end{array}$ & $\begin{array}{l}\text { Vitamin P, mg / } \\
100 \mathrm{~g}\end{array}$ \\
\hline Nane & 10 & 8 & 1 & 22 & 32 \\
\hline Babiye leto & 9 & 8 & 2 & 13 & 18 \\
\hline Hercules & 10 & 7 & 3 & 18 & 19 \\
\hline Kalashnik & & & & \\
\hline
\end{tabular}




\begin{tabular}{|c|c|c|c|c|c|c|}
\hline \multirow{4}{*}{ Impact Factor: } & ISRA (India) & $=3.117$ & SIS (USA) & $=0.912$ & ICV (Poland) & $=6.630$ \\
\hline & ISI (Dubai, UAE & $=0.829$ & РИНЦ (Russia) & $=0.156$ & PIF (India) & $=1.940$ \\
\hline & GIF (Australia) & $=0.564$ & ESJI (KZ) & $=8.716$ & IBI (India) & $=4.260$ \\
\hline & JIF & $=1.500$ & SJIF (Morocco) & $=5.667$ & OAJI (USA) & $=0.350$ \\
\hline
\end{tabular}

\begin{tabular}{|l|l|l|l|l|l|}
\hline Polyanka & 13 & 9 & 3 & 21 & 6 \\
\hline
\end{tabular}

\section{Conclusions}

Large dense berries stand out remontant varieties of raspberries - Brilliyantovaya, Heracles, Polyanka, Kalashnik. A high level of accumulation of biologically active substances is distinguished by the remontant sorts Brilliyantovaya, Babiyeleto, Polyanka, Kalashnik, in berries whose content of vitamin $\mathrm{C}$ is $22.2-31.9 \mathrm{mg} / 100 \mathrm{~g}$, anthocyanins 77.8-174.0 mg / $100 \mathrm{~g}$ High-quality finished product in the production of jam and fast freezing can be obtained by using raspberry berries of repair varieties: Babiyeleto, Kalashnik, Polyanka, Heracles, Brilliyantovaya.

\section{References:}

1. Bokhan, I. A., \& Rotachev, S. A. (2008). Evaluation of new remontant raspberry varieties according to the biochemical composition of the berries. Fruit and berries growing in Russia: Coll. scientific works / T.H1H / VSTISP. (pp.25-27). Moscow.

2. Kazakov, I. V., \& Evdokimenko, S. N. (2007). Raspberry remontantnaya. (p.288). Moscow: GNU VSTISP.

3. Prichko, T. G., et al. (2009). Peculiarities of accumulation of biologically active substances in the raspberries of the south of Russia. Fruit and berry growing in Russia: Coll. scientific works / T.XX11. 4.2. / VSTISP. (pp.367-376). Moscow.

4. Yaschin, A. Y. (2008). Injection flow system Amperometric detector for the selective determination of antioxidants in food and beverages. Russian Chemical Journal, №2, pp.130-135.

5. (2013). Program and methods of sorting out fruit, berry and nut crops. Editorial Board: T.A. Lobanov et al. / VNIIS them. Michurin. (p.495). Michurinsk.
6. Bridge, O. A. (2009). Reproduction of plants of RUBUS IDAEUS L. by apron as a method of accelerating the selection process. O.A. Mostovoy, V.N. Sorokopudov. Bulletin of the Krasnoyarsk State Agrarian University, № 5, pp.46 - 49.

7. Nevostruva, E. (2009). Remontnaya raspberry in the middle Urals. Main boutique, № 7, pp.53 - 55.

8. Nemtsova, E. V. (2009). Optimizing the diagnosis of raspberry virus-growing dwarfism using RT PCR: Dis. Cand. S.-H. sciences. (p.163). Bryansk.

9. Light, L. V. (2009). The results of the study of the quality of the fruits of raspberry remontant type in the Republic of Belarus. Fruit and berry growing in Russia: Coll. scientific Works /VSTISP. Moscow, Vol. 22, No. 2, pp.117 -122.

10. Lomachinsky, I. A. (2006). Long-term preservation of berries using cold processing / VA. Lomachinsky, N.S. Shishkin // Chief agronomist, № 6 , pp. $69-70$. 


\begin{tabular}{|c|c|c|c|c|c|c|}
\hline \multirow{4}{*}{ Impact Factor: } & ISRA (India) & $=3.117$ & SIS (USA) & $=0.912$ & ICV (Poland) & $=6.630$ \\
\hline & ISI (Dubai, UAE & $=0.829$ & РИНЦ (Russia) & $=0.156$ & PIF (India) & $=1.940$ \\
\hline & GIF (Australia) & $=0.564$ & ESJI $(\mathrm{KZ})$ & $=8.716$ & IBI (India) & $=4.260$ \\
\hline & JIF & $=1.500$ & SJIF (Morocco) & $=5.667$ & OAJI (USA) & $=0.350$ \\
\hline
\end{tabular}

